cartography bulletin board

\section{EUREKA CARTOGRAPHY}

by Susan Waldorf, President

Eureka Cartography

Eureka Cartography of Berkeley, California is the largest provider of custom map production services in the Western U.S. Clients include magazine, textbook, guidebook and telephone directory publishers, advertising agencies, government agencies, visitors bureaus, environmental organizations and transit agencies. Recently, Eureka has been active in multimedia, producing hundreds of maps for $\mathrm{CD}$-ROM titles and interactive textbooks. If Fodors, Sierra Club, GTE, U.S. West, Mindscape, Macmillan, and the U.S. Forest Service publications are familiar to you, you've probably seen a Eureka map or atlas. Our clients think of us as their own in house mapping department, from initial concept development through final output.

Founded eleven years ago, the company has grown to a staff of fifteen professionally trained geographers and cartographers with expertise in digital map design and production. The size of the staff enables Eureka to handle both large and small projects with the same attention to customer service. Variety is the norm at Eureka; in addition to traditional cartographic designs, the staff has produced game boards, puzzles, maps on Plexiglas, maps for astrological charting, maps for children, and maps for courtroom presentations.

Eureka has complied detailed base maps for the Bay Area, California, the U.S., most major cities, and all countries worldwide at multiple scales. Typically, clients work with Eureka's senior cartographers to identify the content and the look of a map, carefully tuning each design element to support the intended use of the product in print or digital form. Clients preview their maps before final production to ensure proper map coverage, content, style, and layout. Eureka produces raster or vector digital files, high quality plots, final films and proofs, or printed maps, depending upon the client's target medium.

In addition to customer services, Eureka is now a publisher of map products, with seven titles to be printed this year. In a joint venture with Map Link of Santa Barbara and Allan Cartography of Medford, Oregon, Eureka will also publish high quality maps and atlases under a newly created imprint, Benchmark Maps. Digital versions of Eureka maps may now also be previewed and purchased on-line through PNI, a new stock photoservice for print and multimedia editors and producers.

Eureka employs a wide range of GIS, desktop publishing, and graphics software tools including Autocad, Microstation, MapInfo, Freehand, Photoshop, Quark and PageMaker. In addition to databases developed in-house, Eureka utilizes geographic and demographic databases from a number of commercial data providers. The San Francisco Bay Area provides a rich supply of service bureaus, conversion shops, illustrators, photo researchers, travel writers and other specialized services Eureka utilizes as required.

On the next page (pages 38-39) is a color map of Fresno, California created by Eureka Cartography. It is a convention and visitors bureau map, designed to attract commerce to the region. It is a hybrid cartographic design, incorporating accurate road and city information with illustrative elements to give readers a positive image of the area. Cartographic license was taken to represent surrounding attractions without losing the accurate navigational information a visitor requires. The map appears in a regional magazine and other derivative publications. Cartographers Stacy Wright and Kevin Kolb used Freehand 5.0 to create the overview and inset maps.

\section{CARTOGRAPHY AT THE 1995 ASSOCIATION OF AMERICAN GEOGRAPHERS MEETING}

\section{by Jim Anderson, Director \\ Florida Resources \& Environmental Analysis Center \\ Florida State University}

The recently concluded annual meeting of the Association of American Geographers that was held in Chicago included participation by many NACIS members and provided a variety of sessions on many aspects of cartography, numerous workshops, and a site visit to Rand McNally's company headquarters.

The majority of the cartography related paper sessions were sponsored by the Cartography Specialty Group or co-sponsored in conjunction with the GIS Specialty Group. Four sessions on theoretical cartography were held: Cartographic Techniques, Computer Applications in Cartography, Cartographic Symbolization, and Cartographic Symbolization and Cognition. A session (similar to one held last year) on National Science Foundation Equipment Grants provided information to departments that are considering setting up a GIS or computer cartography lab. This year's Student Honors Paper Competition session had representation from only three universities. I would urge you to encourage your students to submit a paper for this continued on page 40 
continued from page 37 session next year. A cash prize is awarded for all papers that are accepted, as well as an additional award for the winning paper.

A session on Map Use as a Field of Study examined various ways that maps are being used in natural hazard situations and environmental studies. This session also included a paper on how visualization and multimedia are changing the concepts of map use. There was also a session that focused on some problems and solutions of digital map production and publication. Participants from the University of WisconsinMilwaukee, the University of Tennessee, the University of Oregon, and the H.M. Gousha Company discussed their experiences in producing digital, booksize and large-sheet format map products.

At this year's meeting there was a dramatic increase in the number of sessions and papers that were devoted to multimedia. Three sessions were jointly sponsored by the AAG Multimedia Software Committee, the AAG Commission on College Geography, and the Geographic Information Systems and the Geography Education specialty groups. The sessions, Innovations in Hypermedia and Multimedia I, II, and III, dealt with the development of curriculum support materials using multimedia techniques and how these materials are used in the classroom. It was evident from the sessions that several cartography labs have become involved in developing supplemental materials for physical and human geography courses as well as for book publishers.

Specific items discussed or presented at the meeting of noteworthy interest were:

\section{The Virtual Department Project} The Virtual Department Project is an ongoing effort to link curricula among geography departments using the Internet and the World Wide Web. The stated goals of the project are to:

- Offer high quality curriculum materials in the form of classroom and laboratory modules that can be used across the Internet by geography students and faculty at any university in the world.

-Develop new types of on-line and interactive research publications that promote collaborative research.

-Work toward global curriculum sharing and integration in geography through the creation of on-line "electronic" textbooks and research materials.

- Share the time and expense of developing hypermedia and multimedia curriculum materials and benefit from materials that might not otherwise be made available commercially.

Phase I of the Virtual Department Project will link geography departments already on-line, inventory existing research and teaching materials, prepare samples of hypermedia materials and research reports, and begin to organize an on-line hypermedia geography journal. Future phases are planned that will sponsor workshops and have sixty credit hours of courses on-line. The following home pages provide information about the project:

-Texas Geography: http:// www.utexas.edu/depts / grg / main.html

-Virtual Department: http:// www.utexas.edu/depts/grg/ virtdept/contents.html

\section{Workshops}

This year's meeting saw an increase in the number of workshops held that related to cartography from four to eight:
- Introduction to Computer

Cartographic Programming in C

- Proficiency with MicroCAM

Mapping Software

- An Introduction to Global

Positioning Systems

- Map Production and Design on the Mac

- Map Design and Production with Corel Draw

- Using ArcView in the Classroom

- Multimedia and the Mac

- Surfer for Windows

Since workshops are a source of revenue for the specialty groups, it would be nice to see this trend continue at next year's meeting.

\section{AAG Committee on Multimedia} For those interested in multimedia, the AAG has established a Committee on Classroom Multimedia Software chaired by Sona Andrews from the University of Wisconsin-Milwaukee. The original charge to the committee was to provide the AAG Council with guidance on where geographers and geography stand with respect to multimedia classroom software and to recommend what the Association should do in this area. The charge has been modified to emphasize the ways that the Association can (and should) play a role in fostering innovative teaching based on multimedia. To provide input to the committee or to receive information about activities of the committee contact Sona Andrews at sona@csd.uwm. edu.

\section{Cartography Specialty Group}

Several items of interest were discussed at the Cartography Specialty Group business meeting. The current membership of the group is six hundred and fortyeight. Keith Clarke from Hunter College, New York is the incoming the chairman. Eugene Turner from California State UniversityNorthridge is the newly elected vice chairman. As vice chairman, 
Gene will be responsible for organizing sessions for next year's program. Suggested session topics include Cartographic Education, Map Use, Historical Cartography, Electronic Publishing, Map Design, Design of Presentations, Critiquing Map Design, and Analytical Cartography. Workshops will also be offered. I would encourage NACIS members to participate by contacting Gene. The deadline for paper submission is sometime in September.

The specialty group will continue to award master's research grants and to sponsor the Student Paper Competition. If you know of students who are conducting thesis research related to cartography they should be encouraged to contact the specialty group. The idea of establishing a service bureau for next year's meeting to assist paper presenters with their graphics was also discussed. The Central Office of the AAG has also asked the specialty group to develop guidelines for graphics used in presentations. This is an ongoing problem which NACIS members should also be aware of when presentations are created for our own annual meeting. One final item of discussion was the feasibility of creating a home page on the world wide web which could be used to distribute minutes, newsletters, a membership directory, and other items of interest.

In conclusion, cartography was well represented at this year's national meeting of the AAG. The Cartography Specialty Group is one of the largest in the Association and is very active in organizing sessions and promoting cartography. I would urge you to participate when possible and to consider making a presentation at next year's meeting in Charlotte to be held April 9-13, 1996. For information contact the AAG, 1710 16th Street NW, Washington, D.C. 20009-3198 or GAIA@AAG.ORG.】

\section{reviews}

\section{BOOK REVIEW}

\section{Thematic Mapping from Satellite} Imagery: A Guidebook. Edited by Jean Denègre. Published on behalf of the International Cartographic Association (ICA) by Elsevier Science, Oxford: Pergammon, 1994. $269+$ xxvi pp. English and French text, 24 images in color, 4 in black and white, preface by D.R.F. Taylor, acknowledgments. Size: $29.2 \mathrm{~cm}$ X $20.3 \mathrm{~cm}$ (11.5" X 8"). Contributors include: Andrzej Ciolkosz, Andrzej B. Kesik, Donald Laurier, Sten Folving, Jean Denègre, Janos Lerner. $\$ 105.00$ hardcover. (ISBN 0-08-042351-5)

\section{Reviewed by Michael P. Peterson Department of Geography/Geology University of Nebraska at Omaha}

The stated purpose of this book is to present methods for producing maps from satellite images. It is intended for "inexperienced satellite imagery users desiring practical guidance on methods employed and their expected results." Of the five chapters, four examine two general technical problems: 1) how to interpret the collected data, and 2) how to integrate the information acquired from conventional cartography. The remaining chapter, by far the longest, describes the methods and includes examples for the production of maps from satellite imagery. This chapter includes most of the black and white and all of the color images.

The first chapter describes the characteristics of different remote sensing satellites, especially for cartographic applications. It examines the spectral, spatial, and temporal resolutions of twenty different satellite systems, including those for weather, oceanography, geology, and environmental applications. The chapter takes a historical approach, beginning with a description of meteorological satellites, then discussing the land observation satellite systems of the 1970s and 1980s, and finally providing an overview of other systems from Russia (COSMOS), India (IRS-IA), Japan (MOS-1), Germany (MOMS), and the U.S. Space Shuttle radar imagery.

The second chapter concerns the process of extracting information from satellite imagery. The fourteen page chapter examines both the methods of visual image interpretation and computerassisted image analysis. The first part of the chapter looks at the elements of the interpretation process, including tone, color, and texture. The second part of the chapter looks at image preprocessing (radiometric and geometric corrections), image enhancement (contrast and spatial enhancement), and image classification (minimum distance to means, parallelepiped, and maximum likelihood). The last part of the chapter examines accuracy in image classification.

The third chapter looks at the methods for combining satellite imagery with maps. Topics include image/map registration, mosaicing, radiometric processing, and GIS techniques. A major part of the chapter concerns the color transformations that are needed to create an image that looks as "natural" as possible for use of a satellite image as a map background.

Chapter four (nine pages) concerns the design and "semiology" of image map representations. A majority of the chapter looks at typology or lettering. Other parts of the chapter cover the relevant cartographic techniques for selection of information, cartographic representation, and design. 